\title{
INFLUENCE OF PACKAGING ELEMENTS ON THE PURCHASE DECISION-MAKING: A STUDY ON THE BAR SOAP USERS OF DHAKA CITY, BANGLADESH
}

\author{
Tanzina AKHTER \\ University of Dhaka, Bangladesh \\ Email: tanzina.mkt@gmail.com \\ MD. NUR-AL-AHAD \\ Toyohashi University of Technology,Japan \\ Email: ahadfbs@gmail.com
}

DOI: 10.52846/MNMK.19.2.01

Abstract:

In this growing competitive market, packaging has become a vital part of the selling process for communication and branding. However, due to the changes in consumer's lifestyle and increasing self-service usage, the packaging is considered a salient salesman for tangible products. So, there is a gap to explore how different combination of packaging elements can impact the buying decision process of FMCG products. Therefore, this paper aims to investigate the influence of different visual and verbal elements on the purchase decision-making of Dhaka city consumers in the context of bar soap. The quantitative research method was adopted using data obtained from 243 residents from three different areas of Dhaka city.Data were then analyzed using Structural Equation Modeling (SEM) with smartPLS version3. The paper concludes that packaging color and background image are significantly related to soap users' purchase decision-making. However, font style, shape, printed information, and materials are found insignificant in this study. Based on these findings, important implications and guidance are provided for the marketers.

Keywords: packaging elements, purchase decision-making, Bangladesh, bar soap, structural equation modeling.

\section{Introduction}

With rapid urbanization and strong economic growth, a developing country like Bangladesh has a base of mid-to-high income consumers who have an increasing amount of disposable income to maintain their lives. The market of beauty and personal care is an ever-growing one that has fragmented and requires continuous branding and product innovation for brands to sustain (Ahmed et al.2018). In this beauty and personal care market, one of the largest categories thatare related to a low - involvement decision of consumers is bath care products. Three types of segments are currently noticed in Bangladesh's soap market- bar soaps, liquid soaps, and shower gels. Due to improved sanitation and hygiene related knowledge, 
consumers (both value \& premium segments) show themost significant preference for bath and shower products. The soap market's current scenario indicates that multiple local and international brands are competing for consumers' share of wallet, which has ultimately created a stagnant and fragmented market environment. Companies are now considering a comprehensive mixture of tools to break the clutter and keep their brands in the consideration set of consumers.

In this recent intensifying competitive environment and changing consumers' lifestyle patterns, growing interest has been seen in packaging design as a marketing communication tool (Kuvykaite, Dovaliene et al., 2009). The successful integration of packaging elements into an effective purchase decision model results in consumers' solution of vast product choices at the point-of-sales (Silayoi\&Speece, 2004). According to Hassan, Leng et al. (2012), designing packaging elements innovatively helps the product stand out from competitors, catches the consumer's attention, and contributes to brand image and recognition. To influence consumers' purchase decision-making, producers and designers attempt to create efficient packaging by using elements such as form, size, color, graphics, material, and flavor (Smith \& Taylor, 2004). Many authors divide the total packaging elements into two different parts. Some authors (Vila \&Ampuero, 2007; Underwood, 2003) undertook two blocks of package elements: graphic elements (color, typography, shapes used, and images) and structural components (form, the size of the containers, and materials). Other authors Silayoi\&Speece $(2004 ; 2007)$, divide the package into two categories of elements: visual elements (graphics, color, shape, and size) and informational elements (information provided and technology). According to Olson and Jacoby (1972), packaging can be defined in a simple form as extrinsic elements of the product. In detail, it is the container for a product, encompassing the physical appearance of the container and including the design, color, shape, and labeling (Arens, 1996). The appealing color, vivid background picture, consumer-friendly package shape, quality-based materials, proper labeling on the package, etc. All these have a significant impact on the consumers' purchase decision-making. Therefore, FMCG companies mainly focus on the verbal and visual elements when designing adequate and attention-catching packaging products.

In Bangladesh, a significant difference exists between lower socio-economic classes and higher socio-economic classes regarding consumers' usage behavior. A substantial portion of consumers here prefer bar soap as their primary personal care product, using it for cleansing and bathing and a shampoo and deodorant (Ahmed et al. 2018). Dhaka city, the capital of Bangladesh with around two crores, considers bar soap as essential personal care products for their daily life (Dhaka, Bangladesh Metro Area Population 1950-2020, 2020). The residents of Dhaka city experience a hot, humid, and wet tropical climate. The annual average temperature of this city is $25^{\circ} \mathrm{C}\left(77^{\circ} \mathrm{F}\right)$; monthly means varies between $18^{\circ} \mathrm{C}\left(64^{\circ} \mathrm{F}\right)$ in January and $32{ }^{\circ} \mathrm{C}\left(90^{\circ} \mathrm{F}\right)$ in May, raising more demand for bar soap to have a healthy and hygienic body. Thus, this study explores the importance of packaging elements in the buying decision-making of different bar soaps.

The previous studies show a good amount of works has been conducted on the packaging. Several studies have been conducted to know the influence of packaging elements on purchase intention (Purwaningsih et al, 2019; Benachenhou, Guerricha et al., 2017); buying decision behavior (Imiru, 2017; Barber \& Almanza, 2006); buying behavior (Ashaduzzaman\& Mahbub, 2016); consumer liking and purchase 
intention (Kim, Lopetchara et al., 2013). Moreover,some papersfocus on the impact of one element of packaging. For example,Kauppinen and Räisänen, (2014) explored the effect of packaging color on consumer attention and product perception. There are many works found on the impact of packaging strategy on a single product. For example- Lunardo and Guerinet, (2007) analyzed the influence of labeling on wine consumption and its authenticity; Gomez et al. (2015) focused on packaging of immediately consumed milk;Aday and Yener, (2014) worked with glass packaging. However, no work is still found regarding the influence of packaging elements on buying decision-making of bar soap. All this previous literature introducesnew research regarding the packaging of bar soap.

Therefore, this study's broad objectiveis to explore the influence of different packaging elements on purchase decision-making among the consumers of Dhaka city in the context of low-involvement goods bar soap. The specific objectives of this study are:

- To determine the different visual and verbal elements of packaging in the context of bar soap.

- To identify the observed variables of visual and verbal aspects of packaging.

- To uncover the influence of these packaging elements on the purchase decision-making of bar soap.

This article is structured as follows- at first, it reviews different kinds of literature related to the packaging elements, buying decision-making, buying intention, etc. Next, a research framework is developed, and hypotheses are formulated to justify the framework. After that, the research methodology and data analysis techniques are discussed. Then the findings of the study are discussed and summarized. The article concludes with showing the limitations and scope of future research and practical implication for Asian businesses in the final section.

\section{Theoratical Background of the Study}

\subsection{Purchase Decision-making}

According to Lysonski et al. (1996), purchase decision-making is a mental orientation of consumers characterized as an approach to make product choices. This approach deals with two types of direction in decision-making, namely cognitive and affectiveexposure (Sporles and Kendall, 1986). Several studies show that lots of factors can influence consumer purchase decision-making.Consumers consider several dimensions, including the amount of information to be collected, the amount of time to be spent, the number of brands to be considered, the amount of money to be paid, etc. According to the consumer behaviorism model, the purchase decision is a part of consumer purchase behavior that consists of five stages: needs recognition, information search, evaluation of alternatives, purchase decision, and post-purchase behavior (Kotler \& Keller, 2012). Moreover, consumers' purchase decision-making is also influenced by the types of products and level of involvement.

\subsection{Packaging Elements}

The packaging elements act as a set of marketing strategy formulation components to capturea high customer share. In various studies related to packaging, features are used to understand their combined effect on consumers' purchasing decision-making. The significance of packaging in marketing 
communication increases, which was investigated in several previous works (Butkeviciene et al. 2008; Gonzalez, Thorhsbury et al., 2007; Vila \&Ampuero 2007; Nancarrow, Wright \& et al., 1998; Prendergast \& Pitt, 1996; Smith \& Taylor, 2004; Underwood et al. 2001; Silayoi\&Speece, 2004; Underwood, 2003; Vazquez, Bruce et al., 2003; Ampuero\& Vila, 2006). According to Smith \& Taylor (2004), efficient package creation requires producers and designers to consider six variables: form, size, color, graphics, material, and flavor. While Kotler\& Keller (2006) identified six different packaging elements including- size, form, material, color, text, and brand, another three authors, namely Vila \&Ampuero, (2007) and Underwood, (2003) classified the packaging elements in two blocks-graphic elements (color, typography, shapes used, and images) and structural elements (form, size of the containers, and materials). Similarly, a classification process was undertaken by Silayoi\&Speece(2004), where two categories were developed, including visual elements (graphics, color, shape, and size) and informational elements (information provided and technology) with the mediating role of time pressure and involvement level. While the visual aspects positively influence buying decisions in the low involvement situation, informational elements play a significant role in higher involvement decision making. In another study, packaging can be identified as a holistic design where the aspects of packaging are considered holistic components to create a brand identity (Orth and Malkewitz, 2006). Some of the most relevant articles on packaging elements are summarized below:

Table 1

Review of related literature

\begin{tabular}{|c|c|c|c|c|c|}
\hline \multirow[t]{2}{*}{ Author (s) } & \multirow[t]{2}{*}{ Year } & \multicolumn{2}{|c|}{ Lists of variables } & \multirow[t]{2}{*}{ Country } & \multirow{2}{*}{$\begin{array}{l}\text { Main outcomes of } \\
\text { the study }\end{array}$} \\
\hline & & $\begin{array}{l}\text { Independent } \\
\text { variable (s) }\end{array}$ & $\begin{array}{l}\text { Dependent } \\
\text { Variable }\end{array}$ & & \\
\hline $\begin{array}{l}\text { Purwaningsih } \\
\text { et al. }\end{array}$ & 2019 & $\begin{array}{l}\text { Graphics, } \\
\text { size/shape, } \\
\text { product } \\
\text { information, and } \\
\text { technology. }\end{array}$ & $\begin{array}{l}\text { Purchase } \\
\text { intention }\end{array}$ & Indonesia & $\begin{array}{l}\text { Packaging color and } \\
\text { shape are the most } \\
\text { significant indicator } \\
\text { of purchase } \\
\text { intention. }\end{array}$ \\
\hline $\begin{array}{l}\text { Banerjee } \\
\text { \&Kedia }\end{array}$ & 2018 & $\begin{array}{l}\text { Color, materials, } \\
\text { Wrapper design, } \\
\text { Innovation \& } \\
\text { practicality, Font } \\
\text { style, labeling, } \\
\text { background } \\
\text { information and } \\
\text { pricing. }\end{array}$ & $\begin{array}{l}\text { Purchase } \\
\text { decision }\end{array}$ & India & $\begin{array}{l}\text { All the elements of } \\
\text { packaging have } \\
\text { effect on purchase } \\
\text { decision making. }\end{array}$ \\
\hline Imiru & 2017 & $\begin{array}{l}\text { Color, image, } \\
\text { materials, } \\
\text { innovation, font } \\
\text { size and printed } \\
\text { information }\end{array}$ & $\begin{array}{l}\text { Buying } \\
\text { decision } \\
\text { behavior }\end{array}$ & Ethiopia & $\begin{array}{lr}\text { All the elements } \\
\text { except rolor, } \\
\text { materials have } \\
\text { positive influence. }\end{array}$ \\
\hline $\begin{array}{l}\text { Benachenhou, } \\
\text { Guerricha et al. }\end{array}$ & 2017 & $\begin{array}{l}\text { Marketing } \\
\text { innovation, visual } \\
\text { and verbal } \\
\text { elements }\end{array}$ & $\begin{array}{l}\text { Purchase } \\
\text { intention }\end{array}$ & Tlemcen city & $\begin{array}{l}\text { All these three } \\
\text { elements directly } \\
\text { affect consumer' } \\
\text { purchase intention. }\end{array}$ \\
\hline $\begin{array}{l}\text { Ashaduzzaman \& } \\
\text { Mahbub }\end{array}$ & 2016 & $\begin{array}{l}\text { Color, image, font } \\
\text { style, design of } \\
\text { wrapper, printed }\end{array}$ & $\begin{array}{l}\text { Buying } \\
\text { behavior }\end{array}$ & Bangladesh & $\begin{array}{l}\text { All the elements are } \\
\text { significant in buying }\end{array}$ \\
\hline
\end{tabular}




\begin{tabular}{|c|c|c|c|c|c|}
\hline & & $\begin{array}{l}\text { information, } \\
\text { innovation. }\end{array}$ & & & $\begin{array}{l}\text { behaviorof } \\
\text { detergent powder. }\end{array}$ \\
\hline Hussain et al. & 2015 & $\begin{array}{l}\text { Color, design, } \\
\text { materials, size and } \\
\text { labeling }\end{array}$ & $\begin{array}{l}\text { Purchase } \\
\text { behavior }\end{array}$ & Pakistan & $\begin{array}{l}\text { All the elements are } \\
\text { significantly } \\
\text { important. }\end{array}$ \\
\hline Zekiri\&Hasani & 2015 & $\begin{array}{l}\text { Label, color, } \\
\text { quality, design, } \\
\text { printed } \\
\text { information, } \\
\text { language, brand } \\
\text { image, innovation } \\
\text { \& practicality, } \\
\text { price. }\end{array}$ & $\begin{array}{l}\text { Buying } \\
\text { behavior }\end{array}$ & Macedonia & $\begin{array}{l}\text { All the elements are } \\
\text { positively correlated } \\
\text { with buying process. }\end{array}$ \\
\hline $\begin{array}{l}\text { Raheem, } \\
\text { Vishnu et al. }\end{array}$ & 2014 & $\begin{array}{l}\text { Color, material, } \\
\text { design of wrapper } \\
\text { and innovation }\end{array}$ & $\begin{array}{l}\text { Buying } \\
\text { behavior }\end{array}$ & Pakistan & $\begin{array}{l}\text { All the elements are } \\
\text { positively } \\
\text { associated in buying } \\
\text { behavior }\end{array}$ \\
\hline $\begin{array}{l}\text { Kim, } \\
\text { Lopetchara et } \\
\text { al. }\end{array}$ & 2013 & $\begin{array}{l}\text { Labels and brand } \\
\text { name }\end{array}$ & $\begin{array}{l}\text { Consumer } \\
\text { liking \& } \\
\text { purchase } \\
\text { intention }\end{array}$ & $\begin{array}{l}\text { North } \\
\text { Carolina }\end{array}$ & $\begin{array}{l}\text { Declared fat content } \\
\text { and brand } \\
\text { influenced overall } \\
\text { liking and purchase } \\
\text { intent for chocolate } \\
\text { milk to differing } \\
\text { degrees. }\end{array}$ \\
\hline $\begin{array}{l}\text { Hassan, Leng } \\
\text { et al. }\end{array}$ & 2012 & $\begin{array}{l}\text { Information, } \\
\text { graphics, color, } \\
\text { shape, size, and } \\
\text { materials. }\end{array}$ & $\begin{array}{l}\text { Purchase } \\
\text { decision }\end{array}$ & Malaysia & $\begin{array}{l}\text { Shape and } \\
\text { information on the } \\
\text { package have a } \\
\text { positive influence. }\end{array}$ \\
\hline $\begin{array}{l}\text { Kuvykaite, } \\
\text { Dovaliene et al. }\end{array}$ & 2009 & $\begin{array}{l}\text { Verbal and visual } \\
\text { elements }\end{array}$ & $\begin{array}{l}\text { Purchase } \\
\text { decision }\end{array}$ & $\begin{array}{l}\text { Kèdainiai } \\
\text { city }\end{array}$ & $\begin{array}{l}\text { Verbal elements are } \\
\text { more important than } \\
\text { visual aspects in } \\
\text { decision-making. }\end{array}$ \\
\hline $\begin{array}{ll}\text { Barber } \quad \& \\
\text { Almanza }\end{array}$ & 2006 & $\begin{array}{l}\text { Shape, color, label } \\
\text { design, and } \\
\text { information }\end{array}$ & $\begin{array}{l}\text { Purchase } \\
\text { decision }\end{array}$ & $\begin{array}{l}\text { The State of } \\
\text { Connecticut }\end{array}$ & $\begin{array}{llr}\text { Labeling } & \text { is } \\
\text { considered an } \\
\text { integral part of } \\
\text { buying decision- } \\
\text { making. }\end{array}$ \\
\hline $\begin{array}{l}\text { Silayoi\& } \\
\text { Speece }\end{array}$ & 2004 & $\begin{array}{l}\text { Graphic, color, } \\
\text { size, shape, } \\
\text { information, and } \\
\text { technology. }\end{array}$ & $\begin{array}{l}\text { Purchase } \\
\text { decision }\end{array}$ & Thailand & $\begin{array}{l}\text { Visual elements are } \\
\text { more significant for } \\
\text { the low-involvement } \\
\text { product, while } \\
\text { informational details } \\
\text { are for high- } \\
\text { involvement } \\
\text { products. }\end{array}$ \\
\hline
\end{tabular}

Thus, based on the previous literature, six elements of packaging are identified for conducting this study. These are visual elements-color, size, packaging materials as per Kuvykaite et al. (2009); font style, background image (Ashaduzzaman \& Mahbub, 2016); and informational element -product information as per the study of Silayoi\&Speece (2004).

\subsubsection{Visual Elements - Packaging color}

Packaging color is classified as one of the non-verbal elements that maximize customer recalls at the sale points, making purchase decisions quickly at the shop 
(Herrington and Capella, 1995). The selection and combination of colorsarecrucial for packaging decisions as it is usually vivid and memorable to customers for brand selection. A potentially strong association can be built between products and color as a cue when it is unique to a particular brand (Silayoi\&Speece, 2004).Moreover, to gain considerable attention at the point of sales (POS), packaging color is one of the most critical factors that can break through the clutter of competitive products and messages (Garber, Burke et al., 2000).

\subsubsection{Visual Elements- Size}

Packaging size has some sort of influence on the purchase decision-making of the customer. The packaging shape discussionalways involves convenient use and carry by customers(Silayoi\&Speece, 2004). To have a competitive edge over other brands, shape innovation is a powerful weapon that builds an image in the consumer mindset by offering the brand a unique identity. Moreover, bringing changes in product packaging changescreates differentiation (Sherwood, 1999) and ensures significant profits at the sales register (Prince, 1994). Uniqueness, fanciness, elongated and straightness- these all are the dimensions of packaging shape that significantly contributetothe purchase decision-making (Hasan, Leng et al., 2012).

\subsubsection{Visual Elements- Packaging materials}

Packaging as one of the essential visual elements is recognized in the study of (Kuvykaite et al., 2009; Silayoi\&Speece, 2004, 2007). However, packaging materials and technical methods vary across product categories (Ashaduzzaman \& Mahbub, 2016). Several studies reveal that consumers prefer packages that is environmentally friendly ((Prendergast \& Pitt, 1996), reused, and recycled more easily (Rundh, 2005). In terms of convenience, consumers demand package that is easy-open, easy-store, easy-carry, and non-breakability (Ashaduzzaman\&Mahbub, 2016), shopability, reliability and portability (Ahmed, Ahmed et al., 2005).

\subsubsection{Visual element- Font style}

The pattern of writing on the package that can grab customer attention is called font style (Ashaduzzaman\&Mahbub, 2016). It is one of the topmost attention-drawing visual elements that can play a significant role in consumer purchase decisionmaking ((Kuvykaite et al., 2009). The up-gradation of I.T. technology has supported this feature. Several authors stressed the importance of proper positioning of this element (Rettie\& Brewer, 2000). This non-verbal element can influence buying behavior as the verbal elements (Butkevicieneet al., 2008). Today's successful companies have specialists who are an expert in mind-blowing font style to catch consumers' attention.

\subsubsection{Visual elements: Background image}

According to the author Ashaduzzaman \& Mahbub (2016), the usage of the character or picture of celebrities, or cartoon or other images used in the packaging are called background images. In low-involvement products, evaluation of attributes is considered less critical for which graphical works like background image areessential (Grossman and Wisenblit, 1999). A product with solid graphic design in its package can attract consumers at the point-of-sale when they are under time pressure, leading them to impulse buying (Herrington and Capella, 1995; Hausman, 2000). While verbal elements (printed information) transmit the information which affectsthe consumer's cognitive orientation, Visual elements (image and picture) of the package transmit the information which affects the consumer's emotions (Silayoi\&Speece, 2004). 


\subsubsection{Informational or verbal elements- Printed information}

Packaging as the primary vehicle for communication with the consumer provides details about the product at the point of sales, including the nutritional value, added ingredients, country of origin, the producer, and best before date. Informational elements of the package play a vital role in decision-making (Silayoi\&Speece, 2004, 2007; Rita, 2009; Kuvykaite et al., 2009). As an essential component of an overall marketing mix, printed information on the package supports advertising claims, establishes brand identity, enhances name recognition, and optimizes shelf space allocations (Deliya and Parmar, 2012). Informational elements are increasingly becoming more important to consumers as they influence choice sets and create product credibility by reducing uncertainty (Silayoi\&Speece, 2004). In purchasing FMCG products, consumers consider printed information in evaluating products and changing purchase decisions (Ashaduzzaman\&Mahbub, 2016). Today's health and nutrition-conscious consumers pay more attention to labeling information as they use it extensively during purchase time and using the time (Coulson, 2000).

\section{Conceptual Model and Hypotheses Formulation}

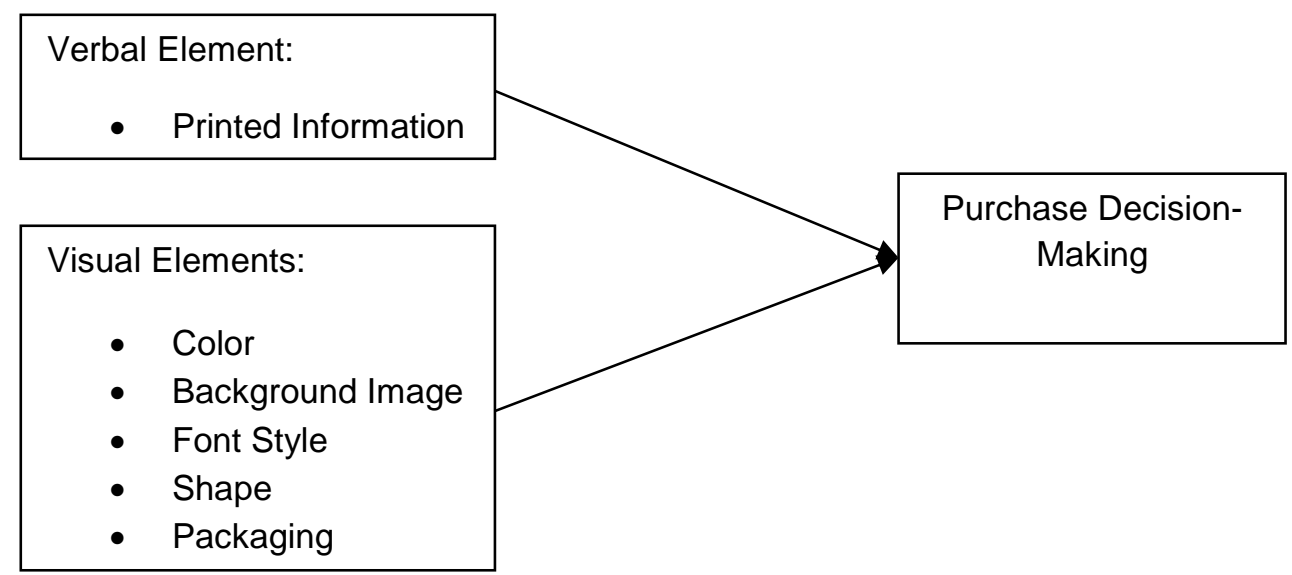

Figure 1. Proposed Conceptual framework for the Study

$\mathrm{H}_{1}=$ The packaging color has a positive influence on making purchase decisions of bar soap.

$\mathrm{H}_{2}=$ The packaging background image has a positive influence on making a purchase decision of bar soap.

$\mathrm{H}_{3}=$ The packaging font style has a positive influence on making a purchase decision of bar soap.

$\mathrm{H}_{4}=$ The packaging shape has a positive influence on making a purchase decision of bar soap.

$\mathrm{H}_{5}=$ The packaging materials have a positive influence on making the purchase decision of bar soap. 
$\mathrm{H}_{6}=$ The information on the package has a positive influence on making a purchase decision of bar soap.

\section{Research Methodology}

\subsection{Sampling design and data collection}

In this study, the target population consists of Bangladeshi people who are using bar soap. So individual users of bar soap are the unit of analysis. Three places, including the Shahbag area, Hazaribag, and Matijheel area, have been selected purposively for collecting data. The participants of this survey include 243 bar soap users from these three different places of Dhaka city. A quantitative survey method has been undertaken to conduct the research, and data were collected through a structured questionnaire. Data were collected from the users across Dhaka city using the online convenience sampling method to test the hypothesis. The respondents were asked to indicate their level of agreement or disagreement with a series of statements regarding their purchase decision-making of bar soap. A total of 243 respondents filled up the questionnaire online from September to October 2020. After the careful screening of the returned answers, 32 questionnaires were excluded due to the incomplete information, and 211 responses were retained for subsequent statistical analysis. The sample consists of $44.5 \%$ male and $55.5 \%$ female respondents from Shahbag, Hazaribag, and Mathijheel area in Dhaka city.

\subsection{Measurement Instrument}

In this study, the independent variables consist of verbal and visual elements of packaging, whereas the dependent variable is the purchase decision-making of consumers. The scale items for measuring packaging elements were adopted from different previous studies. The latent constructs and their observed variables are shown in table 2.

The survey questionnaire is divided into three parts. The first section of the questionnaire includes respondents' demographic informationabout gender, age, marital status, education level, and occupation. The second section contains questions related to this study, such as whether the respondent notices bar soap packs when purchasing, whether they prefer an aesthetic color combination on the package, and so on. The final section includes questions related to the packaging elements and purchase decision-making, respectively. A five-point Likert scale indicatesthe respondent's level of agreement or disagreement regarding the statements. To pre-test the questionnaire, a pilot study was conducted on 12 respondents. Their feedback was incorporated to improve the questionnaire before distributing it to the actual sample. 
Constructs and list of measured variables

\begin{tabular}{|c|c|c|}
\hline Constructs & Measured Variables & Study Source \\
\hline $\begin{array}{l}\text { Packaging Color (PC) } \\
\text { Background Image } \\
\text { (BI) } \\
\text { Font Style (FS) }\end{array}$ & $\begin{array}{l}\text { Attention-catching body-color } \\
\text { Attractive combination of fonts } \\
\text { color } \\
\text { Relevant image, logo on the } \\
\text { package } \\
\text { Celebrity picture on the package } \\
\text { Attractive pattern of writing } \\
\text { Appealing graphic design on the } \\
\text { package }\end{array}$ & $\begin{array}{l}\text { Ashaduzzaman\&Mahbub } \\
\text { (2016) }\end{array}$ \\
\hline Packaging Shape (PS) & $\begin{array}{l}\text { Unique package shape } \\
\text { More elongated package shape }\end{array}$ & Hassan et al. (2012) \\
\hline $\begin{array}{l}\text { Packaging Materials (PM) } \\
\text { Printed Information (PI) }\end{array}$ & $\begin{array}{l}\text { Easy- to- open } \\
\text { High-quality material } \\
\text { Environment- friendly package } \\
\text { Manufacturer information } \\
\text { Country-of-origin information } \\
\text { Quality of information }\end{array}$ & \\
\hline $\begin{array}{l}\text { Purchase Decision- } \\
\text { Making (PDM) }\end{array}$ & $\begin{array}{l}\text { The user considers the } \\
\text { packaging of soap while making } \\
\text { a purchase decision. } \\
\text { Users will recommend others } \\
\text { about the soap that has an } \\
\text { appealing package design }\end{array}$ & $\begin{array}{l}\text { Schlegelmilch, Bohlen et al., } \\
\text { (1996). }\end{array}$ \\
\hline
\end{tabular}

\subsection{Analysis of Data}

For analyzing the data collected through an online questionnaire, SmartPLS software version 3 was used. The quantitative data were analyzed by using Structural Equation Modeling (SEM) to test the hypotheses developed for this study. Descriptive statistics were adopted to provide a narrative view of the total study. Moreover, multicollinearity among the independent variables can be detected by using collinearity statistics. Apart from this, the scale items' reliability and validity were established by using the score of composite reliability (C.R.). 


\section{Results and Interpretations}

5.1 Descriptive Analysis

Table 3

Demographic profile of sample

\begin{tabular}{|c|c|c|c|}
\hline Item & Description & Frequency & percentage \\
\hline Gender & $\begin{array}{l}\text { Male } \\
\text { Female }\end{array}$ & $\begin{array}{l}94 \\
117\end{array}$ & $\begin{array}{l}44.5 \\
55.5\end{array}$ \\
\hline Age (Years) & $\begin{array}{l}16-25 \\
26-35 \\
36-45 \\
46-55 \\
55-65\end{array}$ & $\begin{array}{l}125 \\
52 \\
17 \\
10 \\
7\end{array}$ & $\begin{array}{l}59.2 \\
24.6 \\
8.1 \\
4.7 \\
3.4\end{array}$ \\
\hline Marital Status & $\begin{array}{l}\text { Single } \\
\text { Married }\end{array}$ & $\begin{array}{l}32 \\
179\end{array}$ & $\begin{array}{l}15.2 \\
84.8\end{array}$ \\
\hline Education level & $\begin{array}{l}\text { Graduate } \\
\text { High school/College } \\
\text { Post-graduate and } \\
\text { above } \\
\text { Undergraduate }\end{array}$ & $\begin{array}{l}118 \\
1 \\
56 \\
36 \\
4\end{array}$ & $\begin{array}{l}55.9 \\
.5 \\
26.5 \\
17.1\end{array}$ \\
\hline Occupation & $\begin{array}{l}\text { Entrepreneur } \\
\text { Govt. official } \\
\text { Professional } \\
\text { Student } \\
\text { unemployed }\end{array}$ & $\begin{array}{l}10 \\
27 \\
148 \\
22\end{array}$ & $\begin{array}{l}1.9 \\
4.7 \\
12.8 \\
70.1 \\
10.4\end{array}$ \\
\hline
\end{tabular}

\subsection{Ranking of Mean and S.D. scores}

This study's primary analysis is actually done by using mean and standard deviation values of all independent variables. Rankings were assigned based on the calculated values of mean scores.

Table 4

Descriptive statistics of packaging elements

\begin{tabular}{llll}
\hline Packaging Elements & Mean & SD & Rank \\
\hline Packaging color & 3.72 & 1.07 & 3 \\
Background image & 3.19 & 1.25 & 6 \\
Font style & 3.52 & 1.11 & 5 \\
Packaging shape & 3.55 & 1.14 & 4 \\
Packaging Materials & 3.94 & 1.13 & 2 \\
\hline Printed information & 4.21 & 1.06 & 1 \\
\hline
\end{tabular}


Table 4 represents that the Variable printed information has the highest mean score $(M=4.21)$ compared to the rest of the variables, providing rank 1 . On the other hand, the background image has the lowest mean value of $(M=3.19)$. Apart from the background image, the rest of the variables generate average mean scores ranging from 3.50 to 3.95. Looking at the S.D. values of variables, it illustrates that background image and packaging shape have more significant variation comparedto others.

The quantitative analysis of the data has been performed by employing Structural Equation Modeling (SEM). Because of the complexity of the model developed for this study, a Partial Least Square (PLS) technique was used with running 5000 subsamples bootstrapping procuring using the software SmartPLS version 3.

\subsection{Reliabilty \& Validity Test for the Study}

At first, confirmatory factor analysis is employed to assess the construct validity of each latent construct of the measurement model (Hair etal. 1998). Construct validity can be assessed in 2 ways-Convergent validity and Discriminant validity. According to Malhotra and Dash (2016), convergent validity is the extent to which the scale correlates positively with other measures of the same construct. Convergent validity can be determined by factor loading and Average Variance Extracted (AVE). High factor loadings mean the observed variables converge on the same construct. AVE can be defined as the variation in the latent construct indicators (Malhotra and Dash, 2016). The value of factor loading and AVE should be above 0.5 (Ling \& Ding, 2006). An AVE of 0.50 or more indicates that $50 \%$ or more of the observed variables' variance can be accounted for by the latent construct.

Table 5

Measurement model summary

\begin{tabular}{lllll}
\hline Constructs & Items & Factor loading & CR & AVE \\
\hline Packaging Color (PC) & PC1 & 0.894 & 0.728 & 0.581 \\
& PC2 & 0.602 & & \\
Background Image (BI) & B11 & 0.854 & 0.751 & 0.602 \\
& BI2 & 0.685 & & \\
Font Style (FS) & FS1 & 0.861 & 0.833 & 0.713 \\
& FS2 & 0.827 & & \\
Packaging Shape (PS) & PS1 & 0.816 & 0.854 & 0.745 \\
& PS2 & 0.908 & & \\
Packaging Materials (PM) & PM1 & 0.693 & 0.771 & 0.529 \\
& PM2 & 0.708 & & \\
Printed Information (PI) & PM3 & 0.778 & & \\
& PI1 & 0.876 & 0.871 & 0.692 \\
Purchase decision-making & PI2 & 0.833 & & \\
(PDM) & PDM1 & 0.782 & & \\
\hline & PDM2 & 0.878 & 0.874 & 0.776 \\
\hline
\end{tabular}

The illustration of the measurement model summary in table 5 shows the constructs with their respective items and factor loadings, C.R. and AVE. The table indicates that each construct's scale items have factor loadings ranging from 0.602 
to 0.908 , which means that the observed variables converge on the same construct. Looking at AVE's values, it indicates that all the constructs have AVE that exceeds the threshold level of 0.50 . The result shows that the convergent validity of the latent constructs has been achieved. Composite reliability(C.R.) of all latent constructs is above the threshold level of 0.70 , ranging from 0.728 to 0.874 .

On the other hand, discriminant validity can be defined as the extent to which a measure doesnot correlate with constructs from which it is supposed to differ (Malhotra and Dash, 2016). It can be obtained bytaking AVE's square root larger than correlation coefficients among all latent constructs (Fornell\&Larcker, 1981). Composite reliability (C.R.) can be defined as the ratio of the total amount of actual score variance to the total score variance (Malhotra and Dash, 2016). This measure is used to determine higher internal consistency where the value should be above 0.70 (Nunnally, 1978; Nunnally, 1994).

Table 6

\section{Discriminant Validity of the latent constructs}

\begin{tabular}{llllllll}
\hline & PC & PDM & FS & BI & PI & PM & PS \\
\hline PC & $0.762^{\mathrm{a}}$ & & & & & & \\
PDM & 0.363 & $0.881^{\mathrm{a}}$ & & & & &
\end{tabular}

$\begin{array}{lllll}\text { FS } & 0.532 & 0.348 & 0.845^{\mathrm{a}} & \\ \text { BI } & 0.382 & 0.411 & 0.459 & 0.776^{\mathrm{a}}\end{array}$

$\begin{array}{lllllll}\text { PI } & 0.126 & 0.214 & 0.15 & 0.16 & 0.832^{\mathrm{a}} & \\ \text { PM } & 0.325 & 0.226 & 0.326 & 0.171 & 0.424 & 0.727^{\mathrm{a}}\end{array}$

$\begin{array}{llllllll}\text { PS } & 0.376 & 0.212 & 0.443 & 0.372 & 0.094 & 0.252 & 0.863^{\mathrm{a}}\end{array}$

Note: Diagonal element is the square root of AVE; off-diagonal elements are the correlations between the constructs.

Table 6 shows the discriminant validity of latent constructs. Here, the AVE's square root values are higher than all the correlations among the latent constructs. Thus, the discriminant validity of the model has been obtained.

\subsection{Analysis of Structural model}

\subsubsection{Assessment of structural model}

In this study, the endogenous construct is the purchase decision-making of consumers, and the exogenous construct is the different types of packaging elements. Assessment of the structural model for this study involves some issues. 


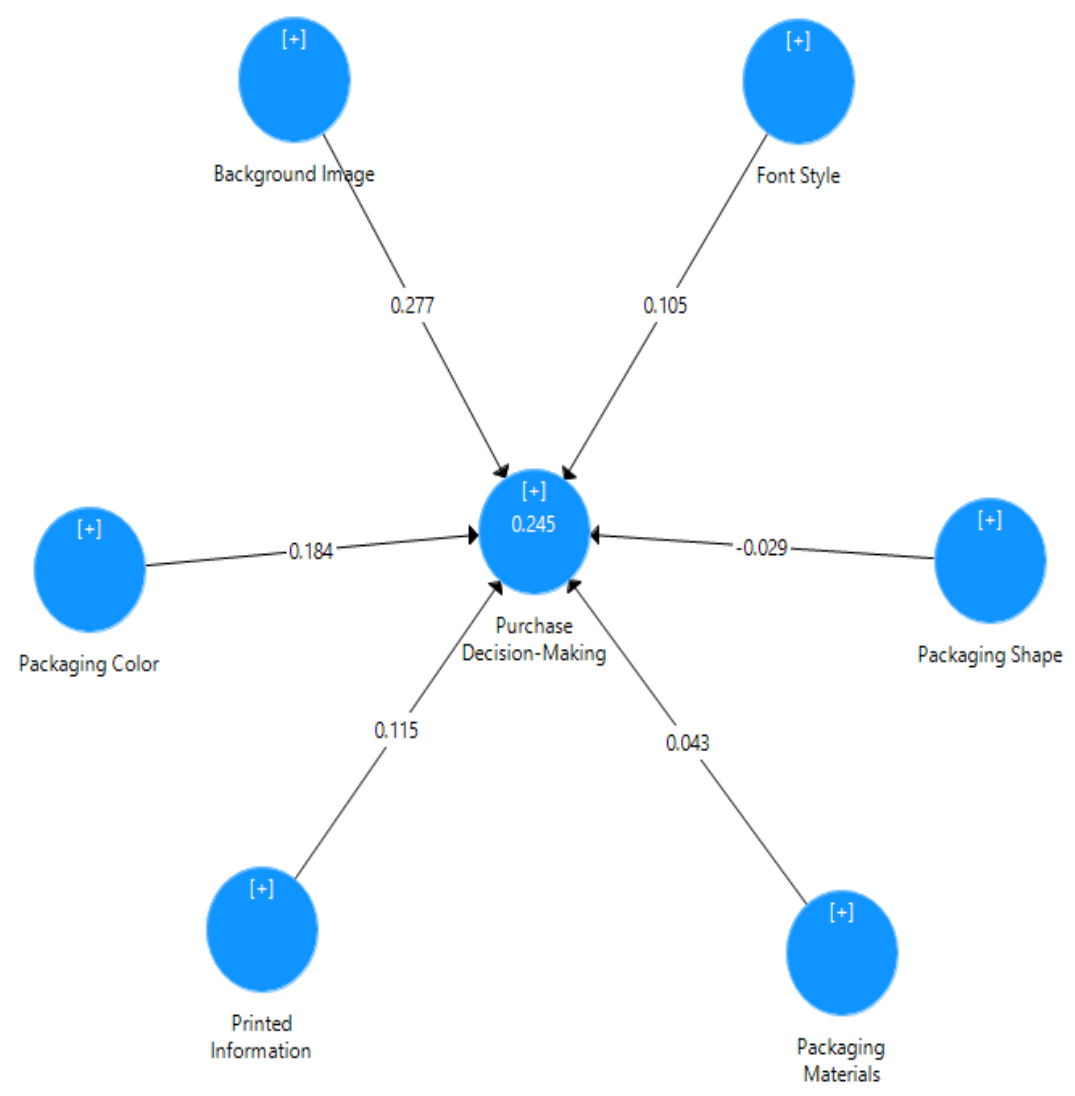

Figure 2. Structural Model

From figure 2, firstly,the examination of the value $R^{2}$ indicates that $25 \%$ variation in the dependent variable (purchase decision-making) can be explained by all the independent variables (packaging elements). Secondly, a multicollinearity test is undertaken to find out any collinearity problem among independent variables. Here, Variance Inflation Factor (VIF) is used to investigate the collinearity problem. A VIF value of 10 is recommended as the maximum level of VIF (Hair et al., 1998). A suggested maximum value of 5 (Rogerson, 2001) and even 4 (Pan \& Jackson, 2008) for multicollinearity is acceptable. Therefore, according to table 6 , the maximum value of VIF is 1.675 in the case of printed information (P.I.), which is within the acceptable level of collinearity. Moreover, according to Hair, Ringle et al.,(2011), tolerance level should be higher than 0.2. Here, in this study, all constructs' tolerance value is higher than 0.2 , which ranges from 0.648 to 0.889 . The conclusion is that no multicollinearity is found for this study. 
5.4.2 Main effects and path coefficient

Estimation of the structural model

Table 7

\begin{tabular}{|c|c|c|c|c|c|c|c|}
\hline $\begin{array}{l}\text { Hypothese } \\
\text { s }\end{array}$ & Path & $\begin{array}{l}\text { Coefficie } \\
\text { nt ( } \beta)\end{array}$ & $\begin{array}{l}t- \\
\text { values }\end{array}$ & $\begin{array}{l}\text { P- } \\
\text { Values }\end{array}$ & Tolerance & VIF & Impact \\
\hline $\begin{array}{l}\text { Hypothesis } \\
1\end{array}$ & $\begin{array}{l}\mathrm{PC} \longrightarrow \\
\mathrm{PDM}\end{array}$ & 0.184 & 2.155 & $0.031^{*}$ & .682 & 1.034 & Significant \\
\hline $\begin{array}{l}\text { Hypothesis } \\
2\end{array}$ & $\mathrm{FS} \longrightarrow \mathrm{DM}$ & 0.105 & 1.109 & 0.267 & .648 & 1.224 & $\begin{array}{l}\text { Insignifican } \\
\mathrm{t}\end{array}$ \\
\hline $\begin{array}{l}\text { Hypothesis } \\
3\end{array}$ & $\mathrm{Bl} \longrightarrow \mathrm{PDM}$ & 0.277 & 3.955 & $0.000^{*}$ & .717 & 1.047 & Significant \\
\hline $\begin{array}{l}\text { Hypothesis } \\
4\end{array}$ & $\mathrm{PI} \longrightarrow \mathrm{PDM}$ & 0.115 & 1.659 & 0.097 & .889 & 1.675 & $\begin{array}{l}\text { Insignifican } \\
\mathrm{t}\end{array}$ \\
\hline $\begin{array}{l}\text { Hypothesis } \\
5\end{array}$ & $\begin{array}{l}\mathrm{PM} \longmapsto \\
\mathrm{PDM}\end{array}$ & 0.043 & 0.529 & 0.597 & .824 & 1.275 & $\begin{array}{l}\text { Insignifican } \\
\mathrm{t}\end{array}$ \\
\hline $\begin{array}{l}\text { Hypothesis } \\
6\end{array}$ & $\begin{array}{l}\mathrm{PS} \longrightarrow \\
\mathrm{PDM}\end{array}$ & -0.029 & 0.429 & 0.668 & .759 & 1.332 & $\begin{array}{l}\text { Insignifican } \\
t\end{array}$ \\
\hline
\end{tabular}

Note: Significant at $5 \%$ level $\left(P^{*}<0.05\right)$; two-tail test, $t=1.96$

In table 7 , the path coefficient, t-values, and $p$-values are used to explore whether the independent variables have a significant impact or not on the dependent variable. Table VII provides a quick view of path coefficients, $t$-values, and $p$-values of all the constructs. The six hypotheses developed for this study are tested using a two-tail test where the result is significant at a $5 \%$ level. If the t-value exceeds 1.96 , then the path coefficient will be considered significant for this study. From the table 6 , the $t$-values of the independent variables are following: $P C=2.155, F S=1.109$, $\mathrm{BI}=3.955, \mathrm{Pl}=1.659, \mathrm{PM}=0.529, \mathrm{PS}=0.429$. Among these six coefficients, two coefficients $(\mathrm{PC}$ and $\mathrm{BI})$ are significantly related to the dependent variable: purchase decision-making of consumers.

On the other hand, the rest of the variables have t-values lower than 1.96, which indicates an insignificant relationship with the dependent variable. Packaging color (P.C.) has $\beta=0.184$ and $t=2.155$; Background Image (B.I.) has $\beta=0.277$ and $t=$ 3.955 , which shows that both these two variables (at $5 \%$ significance level) have a significant impact on the purchase decision-making of consumers. Thus, it is conclusive that hypotheses 1 and 3 are supported and retained in this study, whereas hypotheses 2, 4, 5, and 6 have no significant impact on consumers' purchase decision-making.

\section{Discussion}

This study is all about the elements of packaging, where the supreme objective is to discover the influence of these elements on consumers' purchase decisionmaking. More specifically, this research explores the significant consequences of packaging elements on bar soap purchase decision-making among Bangladeshi 
consumers. The prior literature reviews related to this study have been critically analyzed to determine which area impact of packaging elements has been discussed. Previous studies showthe influence of packaging elements on purchase intention, buying decision, consumer liking, purchase behavior, and so on (Purwaningsih et al., 2019; Benachenhou, Guerricha et al., 2017; Banerjee \&Kedia, 2018; Hussain et al. 2015; Ashaduzzaman\& Mahbub, 2016; Hassan, Leng et al. 2012; Barber \& Almanza, 2006; ZEKIRI \& HASANI, 2015; Kim, Lopetchara et al., 2013). The research objectives of those studies also differed. For example,Purwaningsih et al. (2019) used beverage products in pet bottles to understand packaging's influence on purchase intention. Kim, Lopetchara et al.(2013) used chocolate milk as an object to conduct the research. Ashaduzzaman \& Mahbub (2016) used FMCG object-like detergent powder to conduct the study. To understand the influence of packaging attributes in food products, Hassan, Leng et al. (2012) undertook different types of packaged food items in Malaysia; Barber \& Almanza (2006) investigated wine packaging influence. These earlier studies show that research explicitly discussing the impact of packaging elements on bar soap purchase decision-making is still limited.

The findings here reveal that only two dimensions of visual elements are significantly important for this study between the verbal and visual elements. The results that visual elements of packaging are significant influencers in purchase decision-makingare supported by the study of Silayoi\&Speece, (2004) who found that visual elements have a significant relationship with buying decisions of low involvement products. However, the verbal element of packaging printed on the package has nomeaningful relationship with the dependent variable (purchase decision-making) of this study. Among the visual and verbal packaging elements (packaging color, background image, shape, font style, materials, printed information), the background image is the most significant driver who has $\beta=0.277$. Packaging shape has minor importance for this study which has $\beta=-0.029$. The variable packaging color $(\beta=0.184)$ has a significant influence on consumers' decision-making, which is in line with the previews study of Purwaningsih et al. (2019). However, the study of Purwaningsih et al. (2019) supported packaging shape in the context of beverage product study, which is inconsistent with our findings where the shape is considered as a lesscritical factor.

In designing a fine-tuning package for FMCGproducts like bar soap, companies should think about the excellent combination of those elements to attract consumer's attention. The findings reveal that packaging color and background image are the two drivers that can significantly influence consumers' buying decisions at the supermarket. On the contrary, font style, printed information, shape, materials are the least considered dimensions for this study. The variable packaging color has been measured by two items- attention-catching body color andan attractive combination of font color. The results suggest that a good variety of packet colors with font can influence bar soap's consumer decision-making.

Reckitt Benckiser now offersDettol bathing soap in four different forms- Dettol original, skincare, calm, and aloe vera. Four different types of body color are used to attract consumers(R.B. | Protect, heal and nurture, 2020). The variable background image is denoted by two items-relevant photos, a logo on the package and a celebrity picture. The research indicates that consumers prefer to buy that bar soap brand 
that has a brand logo and popular figure image on the box. This result suggests that brands should develop a brand logo and use celebrity pictures to act as a top-ofmind awareness to consumers in supermarkets. Printed information is measured by three items- manufacturer information, country-of-origin information, and production and expiration date. The findings reveal that consumers are not bothered about the package's data as it is the low-involvement product that is brought frequently. Three items measure packaging materials: accessible- to- open, high-quality fabric, and environment-friendly packaging.Again, because of the low-involvement nature of bar soap, consumers hardly think about its packaging materials. But it's a good sign that some brands are trying to focus on this fact. For example- Dettol is now offering their bathing soap in an anti-fungal package. Packaging shape is measured by unique package shape, and more elongated package shape considered lesscritical drivers. Finally, the variable font style has two items: an attractive writing pattern and appealing graphic design on the package. The findings indicate that having a cute graphic design and an engaging writing style on the soap package may not influence consumers' purchase decision-making in supermarkets.

\section{Conclusion, Limitations, and Scope of future research}

This study investigated the influence of packaging elements on the purchase decision-making of bar soap in Bangladesh. The application of smartPLS showed that two out of six variables, namely packaging color and background image, are considered to have a significant influence on buying decision behavior. The analysis concluded that these two elements aresignificantly crucial for FMCG goods like bar soap goods which are also considered a low-involvement product. Apart from this, the rest four details were found insignificant in this study. The result suggests that soap brands should focus more on developing an eye-catching colorful package with a background image of different figure/ celebrity pictures. However, like every research work, this study also has some limitations in itself. The first limitation is that this study only focuses on one non-food item-bar soap. It may not be generalized to food items. Secondly, a small sample size of 243 was drawn from only three places in Dhaka city. A bigger sample size should be removed from other cities and outside of Dhaka to better the result. Future research could be extended to know packaging element's influence on other product categories or do a comparative study on the effects of various packaging elements on differentproduct categories. Regardless of these limitations, this study has made significant contributions toward existing literaturethrough exploring the influence of visual and verbal aspects of packaging on the purchase decision-making in the context of bar soap among Bangladeshi consumers.

\section{REFERENCES}

Aday, M. S., and Yener, U., (2014), "Understanding the buying behavior of young consumers regarding packaging attributes and labels,"International Journal of Consumer Studies, vol. 38, no. 4, pp. 385-393. 
Ahmed, J., Ahmed, A., Begum, F., Majid, M. and Kabir, G., (2018), "Bangladesh's Dynamic Toilet Soap Market: The Case of Keya,"South Asian Journal of Business and Management Cases, vol. 7, no. 2, pp.156-164.

Ahmed, A., Ahmed, N., \& Salman, A. (2005), "Critical Issues in the packaged food business," British Food Journal,vol. 107, no.10, pp. 760-780.

Ampuero, O. and Vila, N., (2006), "Consumer perceptions of product packaging,"Journal of Consumer Marketing, vol. 23, no. 2, pp. 100-112.

Arens, F. W., (1996), Contemporary Advertising, Irwin, United States of America: Mcgraw-hill Higher Education.

Ashaduzzaman, M. and Mahbub, F., (2016), "Understanding the role of packaging elements on buying detergent powder in Dhaka city: A study on Bangladesh," Asian Journal of Business Research ISSN, vol. 6, no.1, p.2016.

Banerjee, S. and Kedia, A., (2018), "Influence of Packaging of FMCG products on the Consumer's Purchase Decision - A Study," International Journal of Management Studies, vol. Three no. 2, p.36.

Barber, N., \& Almanza, B., (2006), "Influence of Wine Packaging on Consumers' Decision to Purchase,"Journal of Foodservice Business Research, vol. 9, no. 4, pp. 83-98.

Butkevičienè, V., Stravinskienè, J. and Rūtelionienè, A., (2008), "Impact of consumer package communication on consumer decision-making process,"Engineering Economics, vol.56, no. 1, pp. 57-65.

Coulson, N. S., (2000), "An application of the stages of change model to consumer use of food labels", British Food Journal, vol. 102, no. 9, pp. 661-668.

Deliya, M.M.M. and Parmar, M.B.J., (2012), "Role of Packaging on Consumer Buying Behavior - Patan District", Global Journal of Management and Business Research, vol. 12, no. 10, pp. 48-68.

Fornell, C. and Larcker, D.F., (1981), "Evaluating structural equation models with unobservable variables and measurement error", Journal of marketing research, vol. 18, no. 1, pp. 39-50.

Garber, L.L., Burke, R.R. and Jones, J.M., (2000), "The role of package color in consumer purchase consideration and choice", (pp. 1-46), Cambridge, MA: Marketing Science Institute.

Gómez, M., Martín-Consuegra, D. and Molina, A., (2015), "The importance of packaging in purchase and usage behavior", International journal of Consumer studies, vol. 39, no. 3, pp. 203-211.

Gonzalez, M. P., Thorhsbury, S. and Twede, D., (2007), "Packaging as a tool for product development: Communicating value to consumers", Journal of Food Distribution Research, vol. 38, no. 1, pp. 61-66.

Grossman, R.P. and Wisenblit, J.Z. (1999), "What we know about consumers'color choices", Journal of Marketing Practice: Applied Marketing Science, Vol. 5 No. 3, pp. 78-88.

Hair, J. F., Anderson, R. E., Tatham, R. L., \& Black, W. C., (1998), Multivariate Data Analysis (5th ed.), Upper Saddle River, NJ: Prentice Hall. 
Hausman, A., (2000), "A multi-method investigation of consumer motivations in impulse buying behaviour", Journal of Consumer Marketing, Vol. 17, no. 5, pp. 403-426.

Hassan, S.H., Leng, L.W. and Peng, W.W., (2012), "The influence of food product packaging attributes in purchase decision: A study among consumers in Penang, Malaysia",Journal of Agribusiness Marketing, Vol. 5, pp. 14-28.

Herrington, J.D. and Capella, L.M. (1995), "Shopping reactions to perceived time pressure", International Journal of Retail \& Distribution Management, Vol. 23, no. 12 , pp. 13-20.

Hussain, S., Ali, S., Ibrahim, M., Noreen, A. and Ahmad, S.F., (2015),"Impact of product packaging on consumer perception and purchase intention", Journal of Marketing and Consumer Research, vol. 10, pp.1-10.

Imiru, G.A., (2017), "The Effect of Packaging Attributes on Consumer Buying Decision Behavior in Major Commercial Cities in Ethiopia,"International Journal of Marketing Studies, vol. 9, no. 6, pp.43-54.

Jerry C. Olson and Jacob Jacoby, (1972),"Cue Utilization in the Quality Perception Process", in S.V. - Proceedings of the Third Annual Conference of the Association for Consumer Research, eds. M. Venkatesan, Chicago, IL : Association for Consumer Research, pp. 167-179

Kauppinen-Räisänen, H., (2014), "Strategic use of colour in brand packaging", Packaging Technology and Science, vol. 27, no. 8, pp.663-676.

Kim, M.K., Lopetcharat, K. and Drake, M.A., (2013), "Influence of packaging information on consumer liking of chocolate milk", Journal of dairy science, vol. 96, no.8, pp.4843-4856.

Kotler and Keller, (2012), "Marketing management", 14th Edition, Pearson Education.

Kuvykaite, R., Dovaliene, A. and Navickiene, L., (2009), "Impact of package elements on consumer's purchase decision", Economics and management, no.14, pp.441-447.

Ling, C. P., \& Ding, C. G. (2006), "Evaluating group difference in gender during the formation of relationship quality and loyalty in ISP service",Journal of Organizational and End User Computing (JOEUC),vol. 18, no. 2, pp.38-62

Lunardo, R. and Guerinet, R., (2007), "The influence of label on wine consumption: its effects on young consumers' perception of authenticity and purchasing behavior", International marketing and trade of quality food products, 1, pp. 279-291.

Lysonski, S., Durvasula, S. and Zotos, Y. (1996), "Consumer decision-making styles: a multi-country investigation", European Journal of Marketing, Vol. 30 no. 12, pp. 10-21.

Macrotrends.net. 2020. Dhaka, Bangladesh Metro Area Population 1950-2020. [online] Available at:

https://www.macrotrends.net/cities/20119/dhaka/population

Malhotra, N., \& Dash, S., (2016), "Marketing research" (7th ed), Pearson India Education Services Pvt. Ltd, India. 
Nancarrow, C., Tiu Wright, L. and Brace, I., (1998), "Gaining competitive advantage from packaging and labelling in marketing communications", British Food Journal, vol. 100, no. 2, pp. 110-118.

Nunnally, J. C. (1978), "Psychometric theory" (2nd ed.), McGrawHill, New York.

Nunnally, J. C. (1994), "Psychometric theory",(3E), Tata McGraw-Hill Education, India.

Orth, U.R., Malkewitz, K., (2006), "Packaging Design as Resource for the Construction of Brand Identity", In 3rd International Wine Business Research Conference. pp.1-17.

Pan, Y., and Jackson, R. T. (2008), "Ethnic difference in the relationship between acute inflammation and serum ferritin in U.S. adult males",Epidemiology\& Infection, vol. 136, no. 3, pp.421-431.

Prendergast, G.; and Pitt, L., (1996), "Packaging, marketing, logistics and the environment: are there trade-offs?"International Journal of Physical Distribution \& Logistics Management, vol. 26, no. 6, pp. 60-72.

Prince, G. W., (1994), "The contour: A packaging vision seen through Coke-bottle lenses",Beverage World, vol. 113, no. 1567, pp.1-2.

Purwaningsih, I., Surachman, S., Pratikto, P. and Santoso, I., (2019), "INFLUENCE OF PACKAGING ELEMENT ON BEVERAGE PRODUCT MARKETING", International Review of Management and Marketing, vol. 9, no. 6, pp.205-210.

Radeloff, D.J., (1990), "Role of color in perception of attractiveness", Perceptual and Motor Skills, vol. 71, no.1, pp.151-160.

Raheem, A.R., Vishnu, P. and Ahmed, A.M., (2014), "Impact of product packaging on consumer's buying behavior", European Journal of scientific research, vol. 122, no. 2, pp.125-134.

Rb.com. 2020. R.B. / Protect, Heal And Nurture. [online] Available at: https://www.rb.com

Rettie, R., Brewer, C., (2000), "The verbal and visual components of package design", Journal of Product Brand Management, vol. 9, no. 1, pp. 56-70.

Rogerson, P. A., (2001), "Monitoring point patterns for the development of spacetime clusters",Journal of the Royal Statistical Society: Series A (Statistics in Society), vol. 164, no.1, pp.87-96.

Rundh, B., (2005), "The multi-faceted dimension of packaging: Marketing logistic or marketing tool?" British Food Journal, vol. 107, no. 9, pp. 670-684.

Schlegelmilch, B. B., Bohlen, G. M., \& Diamantopoulos, A., (1996), "The link between green purchasing decisions and measures of environmental consciousness", European Journal of Marketing,vol. 30, no. 5, pp. 35-55.

Sherwood, M., (1999), "Winning the shelf wars", Global Cosmetic Industry,vol.164, no. 3, pp.64-67.

Silayoi, P., and Speece, M., (2004), "Packaging and purchase decisions: An exploratory study on the impact of involvement level and time pressure", British Food Journal, vol. 106, no. 8, pp. 607-628. 
Silayoi, P., \&Speece, M., (2007), "The importance of packaging attributes: a conjoint analysis approach",European Journal of Marketing, vol. 41, no. 11/12, pp. 1495-1517.

Smith, P., and Taylor, J., (2004), Marketing communications: an integrated approach (4th edition), Kogan Page Publisher, London.

Sprotles, G.B. and Kendall, E.L., (1986), "A methodology for profiling consumers' decision-making styles", Journal of Consumer Affairs, vol. 20, no. 2, pp. 267-279.

Underwood, R. L., Klein, N. M.and Burke, R. R., (2001), "Packaging communication: attentional effects of product imagery", Journal of Product \& Brand Management, vol. 10, no. 7, pp. 403-422.

Underwood, R. L., (2003), "The communicative power of product packaging: creating brand identity via lived and mediated experience", Journal of Marketing Theory and Practice, vol. 11, no. 1, pp. 62-76.

Vazquez, D., Bruce, M., and Studd, R., (2003), "A case study exploring the packaging design management process within a U.K. food retailer", British Food Journal, vol. 105, no. 9, pp. 602-617.

Vila, N. and Ampuero, O., (2007), "The role of packaging in positioning an orange juice", Journal of Food Products Marketing, vol. 13, no. 3, pp. 21-48.

Yang, S. and Raghubir, P., (2005), "Can bottles speak volumes? The effect of package shape on how much to buy", Journal of Retailing, vol. 81, no. 4, pp.269-281.

Zekiri, J. and Hasani, V.V., (2015), "The role and impact of the packaging effect on consumer buying behavior", Ecoforum journal, vol. 4, pp. 232-240. 